\title{
QUESTÕES SOBRE O “MORAR”: MORADIAS DE CORTIÇO E O CASO DE CURITIBA ${ }^{1}$
}

\author{
Marcela Lino
}

- Enviado em 20/01/2016

- Aprovado em 21/02/2016

O intuito da pesquisa é dar continuidade ao tema que foi objeto de monografia na graduação em Ciências Sociais, no qual se buscou compreender a atual dinâmica do processo de ocupação urbana da cidade de Curitiba, e suas consequências para uma determinada camada da população que habita a área central nos chamados cortiços. Porém a pesquisa monográfica não permitiu abranger significativamente os moradores de cortiço do bairro Centro e adjacências, e devido às dificuldades do campo não foi possível criar um mapeamento destas moradias. Faz-se necessário então ampliar a abrangência da pesquisa, realizando um estudo de caso que permita definir melhor o perfil destes moradores.

Basicamente, cortiços são prédios/ terrenos de propriedade privada que o dono divide em vários espaços os quais são alugados, sem alguma burocracia contratual, e consequentemente sem muitos direitos ao locatário, que habita em condições precárias, que vão de instalações coletivas, como banheiros, a quartos úmidos, escuros, até mesmo sem janela, pequenos espaços utilizados por uma ou mais pessoas, sem alguma privacidade ou conforto (KOWARICK, 2009).

Freyre, em sua obra "Sobrados e Mucambos", demonstra que as casas-grandes e posteriormente os sobrados representaram um sistema social e econômico, que envolviam a produção agrícola, a escravidão e o trabalho, a religião, a família, a educação, a política. Ele afirma que os primeiros cortiços no Brasil foram de holandeses na região do Recife no século XVII; eram sobrados na área urbana, com estilo de construção europeia, desapropriado para o clima tropical da região. Eram extremamente povoados por holandeses, e holandesas que vinham para o Brasil e

\footnotetext{
1 Pesquisa de mestrado em andamento sob a orientação da Professora Doutora Maria Tarcisa da Silva Bega no Programa de Pós-graduação em Sociologia da UFPR.
}

${ }^{2}$ Graduada em Ciências Sociais pela Universidade Federal do Paraná. Endereço eletrônico: lino.marcela@hotmail.com 
tornavam-se prostitutas. O autor comenta que estes sobrados transformados em cortiços e prostíbulos eram extremamente anti-higiênicos, assim como a aglomeração facilitava a proliferação de doenças (FREYRE, 2006).

Vários autores discutiram e ainda discutem a questão dos cortiços, especialmente sobre os casos das cidades de São Paulo e Rio de Janeiro. Nestas cidades, os primeiros cortiços datam do século XIX, também chamados de pocilgas e "cabeça-de-porco", eram ocupados por escravos libertos ou refugiados, imigrantes de diferentes origens, operários. Assim como no século XVII, eram descritos como espaços aglomerados, sujos e suas condições de vida favoreciam a concentração de doenças epidêmicas. Também eram considerados espaços degradantes e de promiscuidade. Situavam-se predominantemente na região central das cidades, sendo para alguns a única opção de moradia.

Curitiba não passou pelo mesmo movimento de "encortiçamento" que estas outras cidades até o início do século XX. Porém após os anos da década de 1970, quando a população urbana cresce a taxas expressivas, houve uma nova dinâmica de ocupação dos prédios vagos dos centros urbanos, por populações de baixa renda, movimento que passa a ocorrer aqui como em outras grandes metrópoles; com a diferença de que agora os migrantes que ocupam estes espaços são do interior do estado do Paraná, de outros estados do país, ou de países latino-americanos. E o que chama a atenção é o fato destas habitações possuírem características semelhantes à configuração antiga, do início do século passado, por sua irregularidade, precariedade e más condições sanitárias.

A região central de Curitiba, composta por bairros como Centro, São Francisco, sofrem pela demanda de infraestrutura de alta tecnologia e novas formas de morar, e o modo extensivo de ocupação do território favoreceu a subutilização e abandono de espaços urbanos consolidados no centro. Com isso houve um movimento da população das classes mais altas, que passaram a morar em bairros próximos, melhor estruturados e mais modernos, ou até mesmo bairros mais afastados, em condomínios fechados que possuam segurança, bom acesso, e áreas verdes, ocasionando o esvaziamento populacional e a deterioração física e econômica da região central, levando à subutilização de uma cara infraestrutura.

Acredita-se na importância de refletir de que maneira a influência da base física do espaço, a ação do Estado e os interesses privados geraram, em cidades com características tão distintas, a existência de uma forma semelhante de morar.

Importante pensar também como moradias em espaços centrais podem ter grande invisibilidade por parte do poder público ou da população. Demonstrando uma segregação social e 
cultural que não atinge somente àqueles que estão literalmente "à margem" espacialmente, nas periferias e favelas mais afastadas do centro urbano.

A literatura nacional, assim como filmes e documentários, podem ser importantes expressões da formação de nossa sociedade. Por isso, levando em conta a invisibilidade dos cortiços, e a maneira pela qual ao longo do tempo os cortiços foram tratados enquanto espaço de moradia e de relações sociais, faz-se necessária a abordagem e análise de algumas destas produções.

O livro "O Cortiço", de Aluísio Azevedo é um exemplo de obra que retrata a vida de brasileiros e imigrantes em um cortiço de Botafogo, no Rio de Janeiro do século XIX. A história narra a construção da chamada Estalagem São Romão pelo português João Romão, e a transformação do espaço em um local amontoado, com muito barulho, confusão. A história perpassa os estereótipos sobre esta forma de moradia, como espaço de promiscuidade, violência, sujeira, e uma mistura de precariedade, exploração, com relações de solidariedade e encontro de culturas.

Os objetivos a serem atingidos com esta pesquisa serão: Ampliar a análise sobre as moradias de cortiço; buscar estender o mapeamento destas formas de moradia, o qual foi iniciado durante a pesquisa monográfica. Realizar uma análise detalhada buscando diferenças e semelhanças físicas ou simbólicas entre a configuração do século XIX destas habitações e a atual; trabalhar com a representação desta forma de habitação coletiva na literatura e no cinema, enquanto forma de retratar a realidade e fazer uma crítica social.

Levando em conta aspectos em relação à construção da pesquisa e métodos de realizá-la, acredita-se que este projeto pode ser realizado utilizando formas de pesquisa empírica, análise de entrevistas e análise de conceitos sociológicos.

Através de entrevista semiestruturada com moradores de cortiços da região central de Curitiba pretende-se analisar o perfil socioeconômico destes moradores, com perguntas objetivas que permitam traçar este perfil e posteriormente analisar os dados de forma estatística.

Através de perguntas abertas o intuito será deixar o entrevistado discorrer sobre alguns aspectos: sua origem; de que maneira acabou por morar ali; com quem mora; como é a relação de vizinhança; como é a relação com o proprietário; existe pretensão de morar em outro lugar; aspectos bons e ruins da moradia; se vê o espaço como um cortiço; entre outros.

Há a pretensão também de relacionar os aspectos das moradias de cortiço da região central de Curitiba, com a permanência dos aspectos das velhas formas de morar de habitações coletivas. Para isto, além de textos teóricos da Sociologia e outras áreas, acredita-se que seja possível relacionar a representação desta forma de moradia e do estereótipo sobre os moradores visto na 
literatura brasileira, com a realidade social. Há a permanência da percepção destes locais enquanto espaços insalubres e aglomerados, habitados por pessoas pobres, e categorizadas como violentas ou perigosas. Assim como ainda são espaços de moradia para imigrantes que estão "à margem”, sem abertura de grandes possibilidades de inserção na sociedade brasileira através de políticas que disponibilizem espaços adequados de moradia, e acesso a empregos qualificados, por exemplo.

\section{REFERÊNCIAS}

AZEVEDO, Aluísio. O Cortiço. Porto Alegre: L\&PM, 2014.

CASTELLS, Manuel. A questão urbana. Rio de Janeiro: Paz e Terra, 1983.

FREYRE, Gilberto. Sobrados e Mucambos: Decadência do patriarcado e desenvolvimento do urbano. 16 ${ }^{\mathrm{a}}$ Ed. - São Paulo: Global, 2006.

KOWARICK, L. Viver em risco: Sobre vulnerabilidade socioeconômica e civil. São Paulo: Editora 34, 2009.

RAUTH, F. H. Análise dos Cortiços da Região Central de Curitiba. Trabalho de Graduação (Bacharelado em Geografia) - Setor de Ciências Exatas e de Tecnologia, Universidade Tuiuti do Paraná. Curitiba, 2002.

SOUZA, N. R. Planejamento urbano em Curitiba: saber técnico, classificação dos citadinos e partilha da cidade. Revista de Sociologia e Política, Curitiba, nº 16, p. 107-122, 2001. 